> processes are occurring?"

However, there was better news for other ESA programmes. Europe's Ariane 5 rocket launcher, which is more expensive than competitors, was the focus of fraught discussions: Germany argued for a more powerful and versatile upgrade, whereas France maintained that it would be better to switch straight to a new and more economical launcher. Following latenight discussions, ministers decided to fund both designs over the next couple of years and to review progress in 2014.

They also reached a deal on how to pay for Europe's contribution to operating the International Space Station between 2017 and 2020. The costs will be covered in kind by a German-backed plan to provide the propulsion and avionics for NASA's Orion manned spacecraft. ESA also agreed to Russian involvement in its twin ExoMars missions, an ambitious programme of orbiters and landers scheduled for launch in 2016 and 2018. NASA pulled out of the project earlier this year.

But ESA's science programme faces a squeeze: it will receive $€ 508$ million a year for the five-year period from 2013 to 2017. Although slightly higher than its 2012 funding of $€ 480$ million, thanks to the contributions from new member states Poland and Romania, after inflation is taken into account this effectively amounts to a cut. Willy Benz of the University of Bern, chair of ESA's Space Science Advisory Committee, says that this could force the agency to delay a future large mission; cancel mission extensions for existing probes; or cancel smaller missions.

Benz thinks that the science programme got less than expected because in hard economic times spending is channelled towards activities that can more directly boost industry, such as designing and building new launchers.

"I would say that the budget outcome was the best we could have hoped for given the economic circumstances," says Benz. "But if you cut budgets in the science programme, you cut science. There is only so much you can save by reducing travel or not making phone calls." -

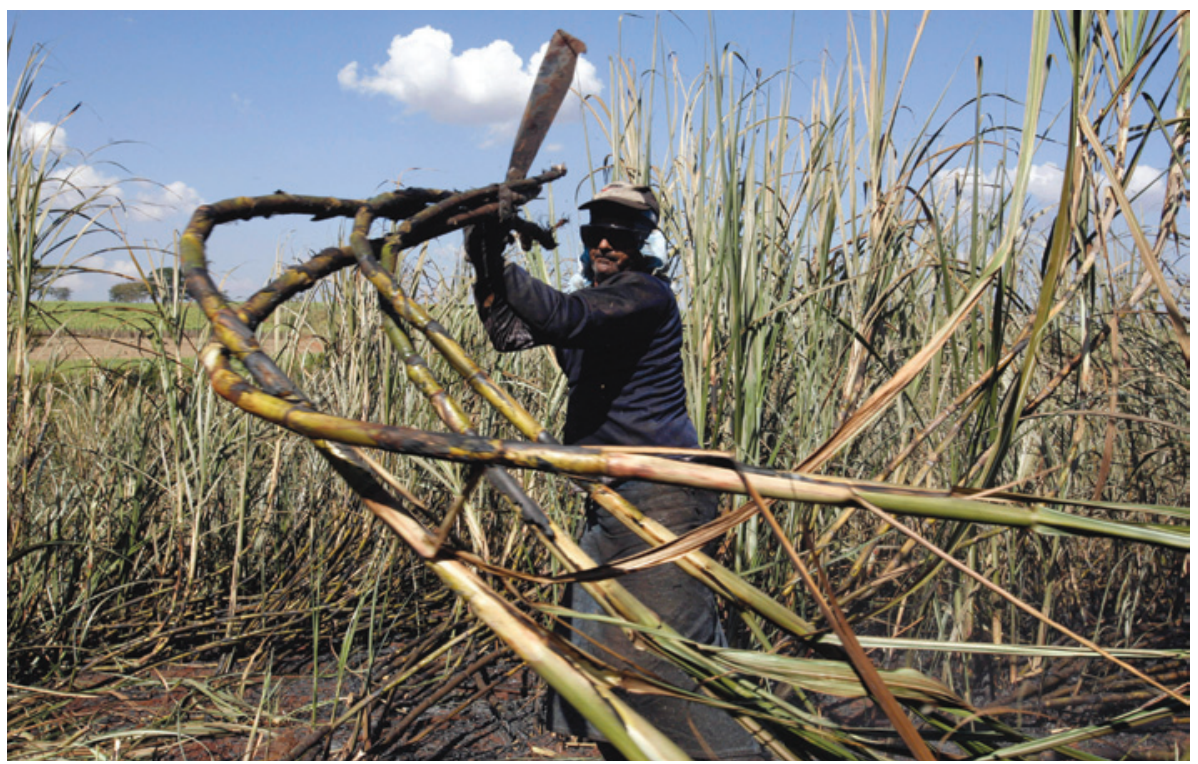

Brazil has struggled to sustain its production of biofuel from sugar cane.

\title{
ENERGY
}

\section{Growth of ethanol fuel stalls in Brazil}

\section{Shortages are a sobering lesson from a biofuels pioneer .}

\section{BY CLAUDIO ANGELO IN BRASÍLIA}

CC new moment for mankind." That was A how Brazil's former president, Luiz Inácio Lula da Silva, described his country's biofuel boom in March 2007. Back then, Brazil was the poster child of ethanol fuel, its output second only to that of the United States. Fermenting the sugars in the country's abundant sugar cane produced a motor fuel that lowered carbon dioxide emissions, and many saw
Brazil as a model for how the world could shed its addiction to oil, creating jobs along the way.

Five years on, Lula's vision has tarnished. Biofuels are falling from grace around the world as critics charge that devoting millions of hectares of agricultural land to fuel crops is driving up food prices and that the climate benefits of biofuels are modest at best. But the fall has been hardest in Brazil, where government policies have compounded the effects of the global economic downturn.
Domestic consumption of liquid ethanol this year has been $26 \%$ lower than for the same period in 2008. Forty-one of the country's roughly 400 sugar-cane ethanol plants have closed over that time. The price of pure ethanol at the pump is so high that in most states it is cheaper to fill up flexible-fuel cars with petrol blends that contain about $20 \%$ ethanol. The shift back to fossil fuels, combined with rapid growth in the number of cars on the roads (see 'Fuelling Brazil's transport boom'), has worsened city smog and caused emissions in the transport sector to spike at about 170 million tonnes of $\mathrm{CO}_{2}$ in 2011, up from less than 140 million tonnes in 2008. "We are increasing the world's GDP: we are buying more oil and spending more on pollution-related health care," jokes Ildo Sauer, who studies energy policy at the University of São Paulo and is a former director of the state oil giant Petrobras.

Brazil's ethanol roller coaster is a sobering example of what can happen when climate and energy planning clash with economic decisionmaking. It began with the 2008 economic crisis, which staunched new investments in the sector just as it was expanding rapidly, and deep in debt. Rather than developing new plantations, the industry fell back on harvesting cane from older, less-productive sites, and average yields plummeted from 115 tonnes per hectare in 2008 to 69 tonnes this year. Combined with two bad harvests, this has forced Brazil to import some 1.5 billion litres of maize (corn) ethanol from the United States over the past 2 years.

But the killer blow came when the government decided to freeze the price of petrol and diesel to keep inflation under control, leaving biofuels less competitive. On the very night that current President Dilma Rousseff gave the closing speech of the Rio +20 conference in June - the final agreement of which promised to phase out fossil-fuel subsidies the government said it would be reducing a federal fuel tax to zero. "We have taken away jobs from agroindustry, stalled growth and worsened the air of our cities for the sake of inflation control," says Luiz Horta, a bioenergy 
researcher at the Federal University of Itajubá.

Meanwhile, the government has tried to stimulate the economy with tax breaks on the sale of new cars. That, combined with the cost of pure ethanol, has meant that "the share of alcohol in our transport fuel matrix has dropped from 55\% in 2008 to 35\%", says André Ferreira, head of the Institute for Energy and the Environment, a think-tank in São Paulo.

According to Antônio de Pádua Rodrigues, technical director and acting president of UNICA, Brazil's sugar-cane industry association, the government knows that the situation is unsustainable. It has promised the industry that petrol prices will go up next year, and that the blend of ethanol will rise from $20 \%$ to $25 \%$, the maximum allowed by law. But it will take time for the industry to bounce back from its poor fortune, and ethanol is likely to remain scarce and expensive for the next two years, say Rodrigues and Horta.

Now, Brazil hopes to tap into a new biofuel source: second-generation ethanol, produced from the tough cellulose in plant stalks. Cellulose is difficult to break down and ferment, but several facilities in the United States are on

$\rightarrow$ NATURE.COM

Read more in

Nature's chemistry and energy Outlook. go.nature.com/q6zodw the verge of making commercial cellulosic ethanol — for example, by using specialist enzymes to break down the longchain cellulose molecules
— and Brazil doesn't want to be left behind.

In December last year, the Brazilian Development Bank launched a 1-billion-real (US\$481-million) credit line to stimulate research and development in cellulosic biofuels and other advanced sugar-cane technologies. The Center for Sugarcane Technology, an industry-sponsored organization based in São Paulo, has taken up a 357-million-real loan to build a cellulosic ethanol plant next year, which would use waste plant matter from conventional sugar-cane fermentation. "We can double fuel yield per hectare when the technology is mature", says Oswaldo Godoy, a project manager at the organization.

The Brazilian Agricultural Research Company (EMBRAPA) is also throwing its weight behind bioenergy. Its president, Maurício Lopes, a geneticist who took office in October, has promised to build up research on biomass technology and double EMBRAPA's funding for that area, which today stands at a modest 24 million real per year. "I want to believe that the current state of the ethanol sector is a temporary blip," he says. Lopes says that Brazil will be "unbeatable" once cellulosic technology matures. "No other country has the logistics we have in place, or the number of different species we can derive ethanol from."

But cellulosic ethanol won't be a quick fix, says Horta. "Nothing shall compete with conventional sugar-cane ethanol until 2050."
FUELLING BRAZIL'S TRANSPORT BOOM

More vehicles and falling ethanol production is prompting a switch to petrol blends.
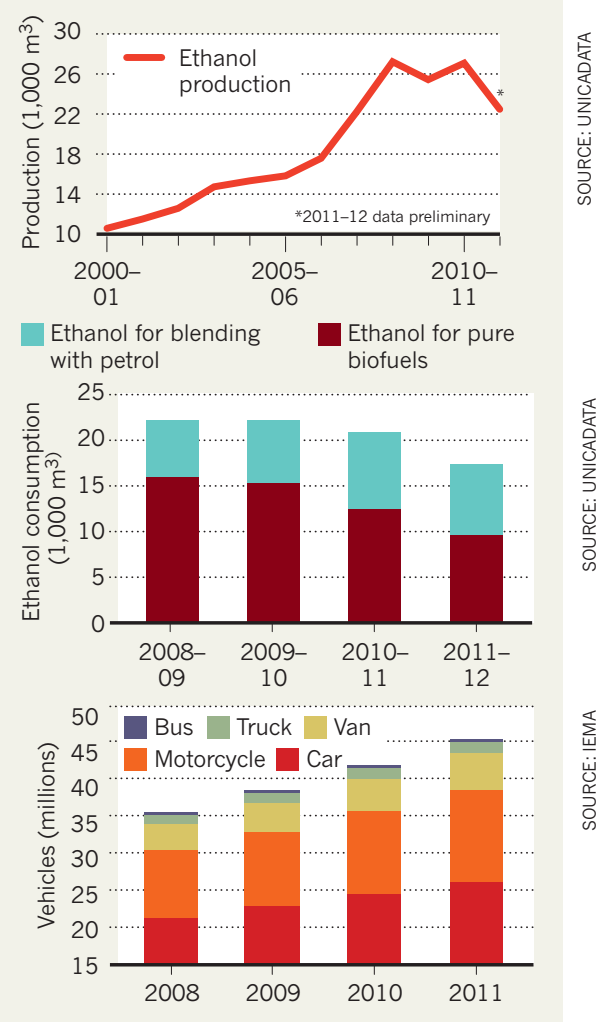

\section{Daily dose of toxics to be tracked}

\section{Exposome studies will tie environmental exposure to biological triggers of disease.}

\section{BY EWEN CALLAWAY}

1 Think of it as a benevolent Big Brother. European researchers are gearing up to monitor thousands of people by giving them smartphones to record the chemicals to which they are exposed every day.

Two projects this week announced that they had won a combined $€ 17.3$ million (US\$22.4 million) from the European Commission to study the 'exposome' - the effects of environmental exposures on health. The researchers hope that the four-year studies will benefit public health in ways that genome research so far has not.

Genome-wide association studies, in which scientists search for genetic variants linked to disease, have failed to fully explain why some people are more susceptible than others to chronic diseases, such as type 2 diabetes. "There's been too much emphasis on genetic factors, which contribute relatively little to disease compared with environmental factors," says Martyn Smith, a toxicologist at the University of California, Berkeley, who is participating in the newly funded Exposomics project. Paolo Vineis, an environmental epidemiologist at Imperial College London, leads the $€ 8.7$-million project.

Subjects will carry smartphones equipped with sensors to measure exposures, and their blood will be analysed to monitor molecular changes. Most participants are already involved in other long-term health studies. One goal is to look for biomarker differences between people walking through areas with low air pollution and those exposed to urban fumes, in order to understand the triggers for conditions such as heart disease, asthma and lung cancer.

Vineis's exposomics approach has already uncovered gene-expression signatures that link people's leukaemia risk with their exposure to heavy metals and other toxic chemicals, for example.

The second project, the $€ 8.6$-million Human Early-Life Exposome, will focus on children and pregnant women. Children are more susceptible to environmental influences because their bodies are smaller and their organs are still developing, says epidemiologist Martine Vrijheid at the Centre for Research in Environmental Epidemiology in Barcelona, Spain, who heads the project. The researchers will track disease biomarkers to assess the effects of environmental exposures on growth, obesity, immune development and asthma. Both projects will generate vast amounts of data, and Vineis and Vrijheid are developing data-sharing policies to enable other researchers to mine the resource.

Interest in exposomics is also growing in the United States. This year, the US National Research Council called for greater investment in exposome research, and the National Institute for Environmental Health Sciences plans to make it a priority, although it has yet to invest in any projects as large as the European efforts, says the institute's David Balshaw. "We see this as a major priority," he says. 